\title{
X-linked juvenile retinoschisis
}

\author{
Retinosquise juvenil ligada ao $X$
}

Cesar Gomes da Silveira ${ }^{1}$, Gabriela Hertz Soares², Jacqueline Provenzano³

\begin{abstract}
Report the case of a male 28 years-old patient, who was referred to Centro de Estudos e Pesquisas Oculistas Associados - RJ, to retina assessment and presented the tipical findings of the X-Linked Juvenile Retinoschisis: A cystoid maculopathy with formation of foveal cysts and schisis of the peripheral retina. It was carried out the conservative management, with attention to the complications.

Keywords: Retinoschisis/diagnosis; Genetic diseases, X-linked/diagnosis; Case reports
\end{abstract}

\section{ReSUMO}

Relatar o caso de um paciente masculino de 28 anos, que foi encaminhado ao Centro de Estudos e Pesquisas Oculistas Associados - RJ, para avaliação de retina e apresentou os achados típicos de Retinosquise Juvenil Ligada ao Cromossomo X: maculopatia cistóide com formação de cistos na fóvea e retinosquise periférica. Foi realizado o manejo conservador, com atenção para as complicações.

Descritores: Retinosquise/diagnóstico; Doenças genéticas ligadas ao cromossomo X/diagnóstico; Relatos de casos

\footnotetext{
${ }^{1}$ Third-year resident physician of Centro de Estudos e Pesquisas Oculistas Associados (CEPOA) - Rio de Janeiro, RJ, Brazil.

2 Third-year resident physician of Ambulatório de Dermatologia Sanitária - Porto Alegre, RS, Brazil,

${ }^{3} \mathrm{PhD}$ at. Head of Centro de Estudos e Pesquisas Oculistas Associados (CEPOA) - Rio de Janeiro, RJ, Brazil.
}

The authors declare no conflicts of interest

Received for publication 18/11/2011 - Accepted for publication 20/01/2013 


\section{INTRODUCTION}

$\mathbf{X}$ -linked juvenile retinoschisis (XJR) is a inherited recessive vitreoretinal degeneration more common in young men characterized by bilateral maculopathy with associated peripheral retinoschisis in $50 \%$ of patients. ${ }^{(1-6)} \mathrm{A}$ prevalence of 1:5000 to 1:28000 is estimated..$^{(1,3)}$

There are descriptions of mutations in the XLRS1 gene $e^{(1-}$ 3.7) , responsible for coding of retinoschisis - a protein that provides adhesion and interaction among cells and among the retinal layers. Defects or absence of its secretion may reduce the adherence between the layer of nervous fibers and the remainder of the sensory retina, forming cystic cavities. ${ }^{(1,6)}$

XJR manifests with reduced visual acuity (VA) between the ages of five and ten years of age, and evolves with progressive visual loss during the first two decades of life. There is the possibility of stabilization of the VA until the fifth or sixth decade, when it can worsen due to macular atrophy, no longer showing the cystic aspect. ${ }^{(5)}$

The visual acuity may be less than 20/200, keeping an average of 20/70 in young adults. Abnormalities in the angle of the anterior chamber such as occlusion angle, strabismus and nystagmus are described as other findings. Vitreous hemorrhage and retinal detachment are the main complications. ${ }^{(1,3,5)}$

The foveal retinoschisis is characterized by the "wagon wheel" standard of radial streaking due to changes in the layer of nerve fibers related to a defect of the Müller cells. ${ }^{(8)}$ Despite the cystic appearance, the exam of fluorescein angiography does not evidence the progressive extravasation characteristic of cystoid macular edema and contributes to the differential diagnosis between pathologies. ${ }^{(8)}$ Peripheral retinoschisis predominantly involves the inferior temporal quadrant, often with large detachments of the inner retinal layers. These changes of the inner layers of the retina predispose vitreous hemorrhage and retinal detachment. ${ }^{(8)}$

\section{CASe Report}

MJS, male, 28, white, single, born and raised in Rio de Janeiro - RJ was referred to the Study and Research Center Opticians Associates - RJ (CEPOA) in February 2011, for retinal evaluation with the diagnosis of XJR. When asked about his family history, he mentioned a brother with whom he is no longer in contact, but who suffers from the same pathology diagnosed.

He brought additional exams from 2008, in which the redfree photography showed the standard of foveolar retinoschisis that extends circumferentially to the parafovelar area. Fluorescein angiography demonstrates cystic changes in the macula without fluid leakage through the subcystoid space (Figure 1). Optical coherence tomography (OCT) (Figure 2) shows foveal cysts with retinal cleavage between the outer and inner plexiform layers in both eyes (BE).

In the eye exam held on 02/01/2011 the visual acuity was 20/ 60 in BE, with the best correction. The biomicroscopy of the anterior segment shows no changes. The intraocular pressure was 17 $\mathrm{mmHg}$ at $04 \mathrm{pm}$ in BE. The retinal mapping performed showed a macular image in foveolar retinoschisis and inferior temporal retinoschisis in the right eye. The left eye showed the same pattern of macular and peripheral retinal images. These findings corroborate the diagnosis of $\mathrm{X}$-linked juvenile retinoschisis.

A new fluorescein angiography (Figure 3) was made in 2011 showing similar appearance to that found in the previous exam. The exam of optical coherence tomography (OCT) (Figure 4) also held in 2011 showed an image of subfoveolar cystic confluence, further changing the fovea architecture and justifying the visual impairment.
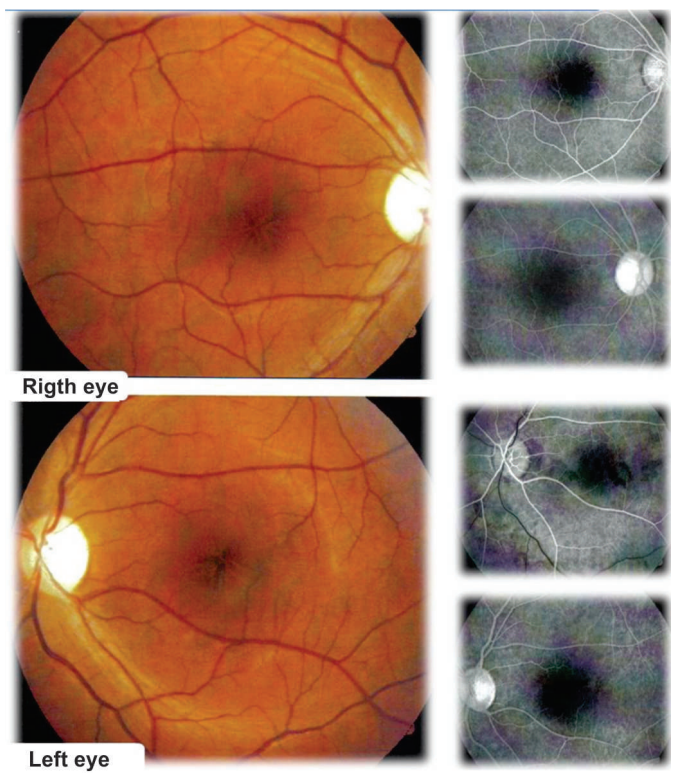

Figure 1: Simple retinography (on the left): macular changes in retinoschisis or "wagon wheel". Fluorescein angiography (on the right): absence of contrast extravasation. 2008.

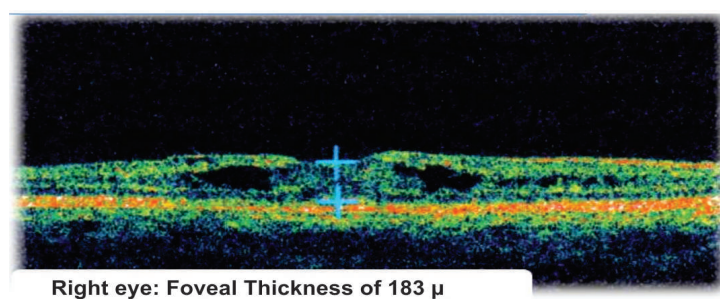

Right eye: Foveal Thickness of $183 \mu$

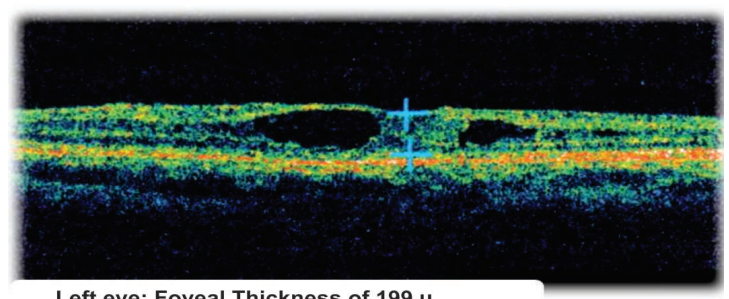

Left eye: Foveal Thickness of 199

Figure 2: OCT images from 2008. Presence of foveal cysts in both eyes.

\section{Discussion}

$\mathrm{X}$-linked juvenile retinoschisis is a relatively rare disorder which determines low visual acuity, mainly by foveolar retinoschisis. ${ }^{(1-6)}$

The inferior temporal bilateral presentation is considered the classic pattern of disease, and the most frequent complications and of worst prognosis are vitreous hemorrhage and retinal detachment. ${ }^{(5)}$ 

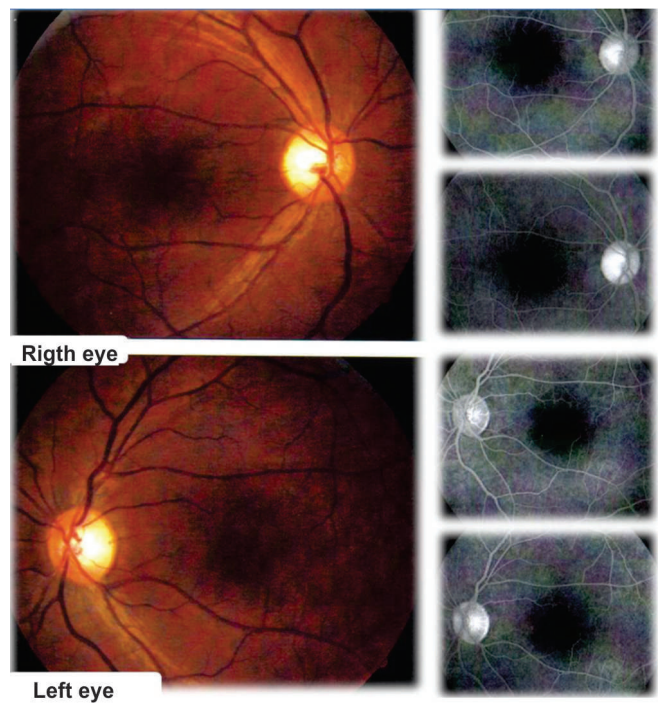

Figure 3: Simple retinography (on the left): macular changes in retinoschisis or "wagon wheel". Fluorescein angiography (on the right): absence of contrast extravasation. 2008.
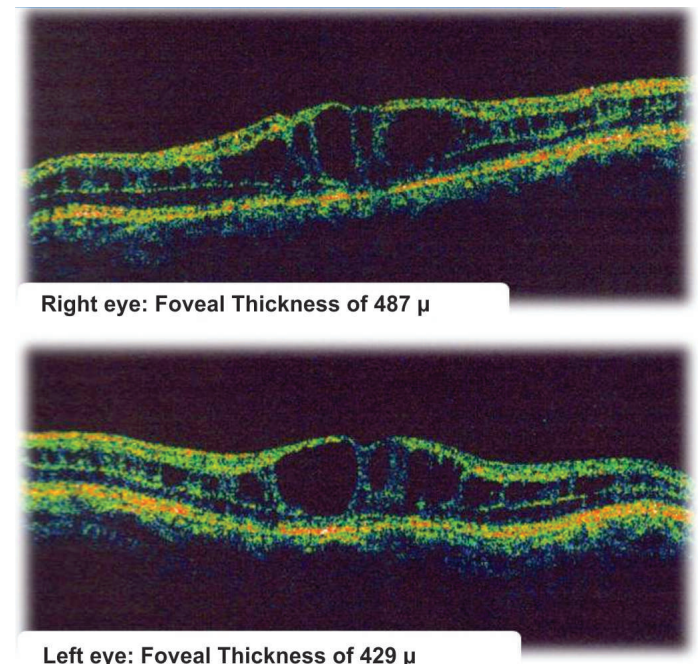

Figure 4: OCT images from 2011. Presence of foveal cysts in both eyes

The fluorescein angiography reaffirms the diagnosis, ruling out the possibility of cystoid macular edema, since there is no extravasation of dye through the macula. ${ }^{(4,5)}$

The optical coherence tomography (Figures 2 and 4) show changes in the evolving foveolar architecture (foveal thickness changes in $\mathrm{BE}$ ), resulting from cysts on the layer of nerve fibers. These cystic formations are also found in the retinal periphery, where they may break to the vitreous and the retina, causing retinal ruptures and hemorrhages. ${ }^{(1,5)}$

The electroretinogram is important in the diagnosis of this disease. The wave amplitude A is normal or close to normal, but wave $B$ has a very reduced amplitude. This reduction in the wave of the $\mathrm{B}$ is justified by the change in the initiation of the electrical impulse in the Müller cells. ${ }^{(5)}$

Literature considers the possibility of stabilization of VA around 20/70 during the second decade of life, with possible progression to atrophic maculopathy around 60 years old. ${ }^{(5,9)}$
The treatment aims to prevent complications that increase visual loss, since nothing has been proven effective in preventing the development of the disease. ${ }^{(2)}$ The possibility of treatment with topical dorzolamide is being studied, but still remains unproven. ${ }^{(6,9,10)}$

In cases of vitreous hemorrhage, some authors suggest the use of photocoagulation of the vessels responsible for the bleeding. ${ }^{(11,12)}$ But in cases of retinal detachment, a tamponade on the rupture and vitrectomy via pars plana are indicated..$^{(2,11)}$

Children who have concomitant strabismus deserve attention, and factors that can induce amblyopia should be minimized. Aid for low vision, and adaptive skills training can help individuals who develop visual loss. Genetic counseling can help identify family members who are carriers of the gene XLRS1, in order to avoid further damage. ${ }^{(2)}$

\section{REFERENCES}

1. Song MK, Small KW, Jayne RP, Law SK, Charles S, Brown LL, et al. Retinoschisis, juvenile [Internet]. [cited 2013 Jan 12]. Available from: http://emedicine.medscape.com/article/1225857-overview.

2. Kugler M. Juvenile retinoschisis: causes progressive loss of vision [Internet]. [cited 2013 Jan 13]. Available from: http:// rarediseases.about.com/od/rarediseasesr/a/retinoschisis05.htm

3. Puech B. X-linked juvenile retinoschisis. Orphanet Encyclopedia. May 2004. Disponível em: http://www.orpha.net/data/patho/GB/ uk-XLRS.pdf

4. Edwards AO, Robertson JE. X-linked juvenile retinoschisis. In: Ryan SJ, editor. Retina. 3rd ed. St. Louis: Mosby; 2001. p. 487-90.

5. Cunha AA, Picanço BC, Almeida GA, Rodrigues NH, Rocha GM. Retinosquise juvenil: relato de caso. Arq Bras Oftalmol. 2008;71(6):878-80.

6. Caye LM, Barbosa PH, Scheid KL, Cardoso IH, Fortes Filho JB. Uso da dorzolamida tópica em paciente portador de retinosquise juvenil ligada ao X. Rev Bras Oftalmol. 2010;69(2):129-31.

7. Sauer CG, Gehrig A, Warneke-Wittstock R, Marquardt A, Ewing $\mathrm{CC}$, Gibson A, et al. Positional cloning of the gene associated with X-linked juvenile retinoschisis. Nat Genet. 1997;17(2):164-70.

8. Shukla D, Rajendran A, Gibbs D, Suganthalakshmi B, Zhang K, Sundaresan P. Unusual manifestations of $\mathrm{x}$-linked retinoschisis: clinical profile and diagnostic evaluation. Am J Ophthalmol. 2007;144(3):419-23.

9. Bastos AL, Freitas BP, Villas Boas O, Ramiro AC. Use of topical dorzolamide for patients with $\mathrm{X}$-linked juvenile retinoschisis: case report. Arq Bras Oftalmol. 2008;71(2):286-90.

10. Apushikin MA, Fishman GA. Use of dorzolamide for patients with X-linked retinoschisis. Retina. 2006;26(7):741-5. Erratum in: Retina. 2007;27(1):128.

11. George ND, Yates JR, Moore AT. X linked retinoschisis. Br J Ophthalmol. 1995;79(7):697-702. Review.

12. Gopal L, Shanmugam MP, Battu RR, Shetty NS. Congenital retinoschisis: successful collapse with photocoagulation. Indian J Ophthalmol. 2001;49(4):265-6. 